\title{
Meanings attributed to complications of ostomy and skin peristhectomy in a public reference service in the Cariri region
}

\section{Significados atribuídos às complicações de estomia e pele periestoma em um serviço de referência na região do Cariri}

\section{Significados atribuidos a las complicaciones de ostomía y piel periestomal en un servicio de referencia en la región de Cariri}

Yterfania Soares Feitosa1,2, Luis Rafael Leite Sampaio 1,2, Déborah Albuquerque Alves Moreira1, Francisco Antonio da Cruz Mendonça ${ }^{3}$, Maria Corina Amaral Viana ${ }^{1}$, Katia Pires Nascimento do Sacramento ${ }^{1}$, Fernanda Maria Silva ${ }^{1}$, Tatyelle Bezerra Carvalho ${ }^{1}$, Yara Lanne Santiago Galdino ${ }^{4}$

ORCID IDS

Feitosa YS (iD https://orcid.org/0000-0002-6021-7557

Sampaio LRL (iD https://orcid.org/0000-0003-1437-9421

Moreira DAA (D) https://orcid.org/0000-0002-2823-8681

Mendonça FAC (iD https://orcid.org/0000-0002-3957-7048

Viana MCA (D) https://orcid.org/0000-0002-6890-9400

Sacramento KPN (iD https://orcid.org/0000-0002-6609-3479

Silva FM (iD https://orcid.org/0000-0002-0504-9896

Carvalho TB (iD https://orcid.org/0000-0001-6515-7963

Galdino YLS (iD https://orcid.org/0000-0001-9242-1715

\section{HOW TO CITE}

Feitosa YS, Sampaio LRL, Moreira DAA, Mendonça FAC, Viana MCA, Sacramento KPN, Silva FM, Carvalho TB, Galdino YLS. Meanings attributed to complications of ostomy and skin peristhectomy in a public reference service in the Cariri region. ESTIMA, Braz. J. Enterostomal Ther., 16: e3918. https://doi.org/10.30886/estima. v16.651 IN

\begin{abstract}
Objectives: To present the meanings attributed by participants or their caregivers in relation to complications of the ostomy and peristomal skin in a referral service in the Cariri region. Methods: Descriptive research, of a qualitative nature, composed of 24 participants with intestinal ostomies. The data were collected in the period of March and June of 2018 in the Service of Health Care of the Person with Ostomy located in the city of Juazeiro do Norte, state of Ceará. The interviews were guided by a structured script and recorded through a mobile app. During the data analysis, participants' answers were transcribed in its full. Results: From the report of the participants, the following meanings for the complications of the ostomy and peristomal skin emerged: aspects related to the quality of the collecting equipment, such as time of permanence of the bag, type of bag and adhesiveness; fragility in the educational process; and effectiveness of surgical procedures. Conclusion: The provision of specialized assistance is necessary so that the orientations of the professionals are directed to the individual needs of each participant, since health care is based on an interpersonal process centered on the integral care of the individual and his or her family.
\end{abstract}

DESCRIPTORS: Stomatherapy; Ostomy; Nursing care.

\footnotetext{
'Universidade Regional do Cariri - Centro de Ciências Biológicas e da Saúde - Departamento de Enfermagem - Crato/CE - Brazil. 2Universidade de Fortaleza - Departamento de Enfermagem - Fortaleza/CE - Brazil.

${ }^{3}$ Centro Universitário Estácio do Ceará - Centro de Ciência da Saúde - Departamento de Enfermagem - Fortaleza/CE - Brazil. ${ }^{4}$ Prefeitura Municipal de Fortaleza - Secretaria Municipal de Saúde - Estratégia Saúde da Família - Fortaleza/CE - Brazil. Correspondence author: Luis Rafael Leite Sampaio | Rua Coronel Antônio Luis, 1161 - Pimenta | ZIP Code: 63105-000 - Crato/CE - Brazil | E-mail: rafael.sampaio@urca.br

Received: Sept 242018 | Accepted: Jan 132019
} 


\section{RESUMO}

Objetivos: Apresentar os significados atribuídos por participantes ou seus cuidadores em relação às complicações da estomia e pele periestoma em um serviço de referência na região do Cariri. Métodos: Pesquisa descritiva, de natureza qualitativa, composta por 24 participantes com estomias intestinais. Os dados foram coletados no período de março e junho de 2018 no Serviço de Atenção à Saúde da Pessoa com Estomia localizado no município de Juazeiro do Norte, estado do Ceará. As entrevistas foram guiadas por um roteiro estruturado e gravadas por meio de um aplicativo de celular. Durante a análise dos dados, as respostas dos participantes foram transcritas na íntegra. Resultados: A partir do relato dos participantes, emergiram os seguintes significados para as complicações da estomia e pele periestoma: aspectos relacionados à qualidade dos equipamentos coletores, como tempo de permanência da bolsa, tipo de bolsa e adesividade; fragilidade no processo educativo; e efetividade dos procedimentos cirúrgicos. Conclusão: A prestação de assistência especializada se faz necessária para que as orientações dos profissionais estejam direcionadas para as necessidades individuais de cada participante, uma vez que a assistência em saúde se encontra pautada em um processo interpessoal centrado no cuidado integral do indivíduo e sua família.

DESCRITORES: Estomaterapia; Estomia; Cuidados de enfermagem.

\section{RESUMEN}

Objetivos: Presentar los significados atribuidos por participantes o sus cuidadores con relación a las complicaciones de la ostomía y piel periestomal en un servicio de referencia en la región de Cariri. Métodos: Investigación descriptiva, de naturaleza cualitativa, compuesta por 24 participantes con ostomías intestinales. Los datos fueron recolectados en el período de marzo y junio del 2018 en el Servicio de Atención a la Salud de la Persona con Ostomía localizado en el municipio de Juazeiro do Norte, estado de Ceará. Las entrevistas fueron guiadas por un guión estructurado y grabadas por medio de una aplicación de celular. Durante el análisis de los datos, las respuestas de los participantes fueron transcritas íntegramente. Resultados: A partir del relato de los participantes, emergieron los siguientes significados para las complicaciones de la ostomía y piel periestomal: aspectos relacionados a la calidad de los equipos colectores, como tiempo de permanencia de la bolsa, tipo de bolsa y adhesividad; fragilidad en el proceso educativo; y efectividad de los procedimientos quirúrgicos. Conclusión: La prestación de asistencia especializada se hace necesaria para que las orientaciones de los profesionales estén dirigidas para las necesidades individuales de cada participante, una vez que la asistencia de salud se encuentra pautada en un proceso interpersonal centrado en el cuidado integral del individuo y de su familia.

DESCRIPTORES: Ostomaterapia; Ostomía; Cuidados de enfermería.

\section{INTRODUCTION}

Ostomy is understood to be a surgically produced opening for temporarily or permanently communicating a hollow organ with the external environment through the skin ${ }^{1}$. Depending on the segment of the externalized organ, the stomies may receive different denominations, such as colostomies (colon), ileostomies (ileal segment), tracheostomy (trachea), among others.

In view of the variability of the ostomies, the intestinal ones are worth mentioning, since the majority of the complications are related to this type of stommy, as both the contact of the effluent with the peristomal skin and the surgical technique used can cause damages that compromise the quality of life (QL) of the person with ostomy².

There are several causes related to the need of making an intestinal stoma, such as traumas, inflammatory bowel diseases, rectal prolapse, severe neurological dysfunction, bladder atrophy, colon, rectum, and bladder neoplasms ${ }^{3}$. However, neoplasias are currently the most common causes of ostomy indication, and colorectal cancer is the most frequent cause of definitive ostomy confecction ${ }^{4}$.

According to the National Cancer Institute, colorectal cancer is the third most commonly diagnosed malignant neoplasm and the fourth leading cause of cancer death, accounting for 1.4 million new cases and nearly 700,000 deaths in $2012^{5}$.

Complications related to the ostomy may be classified as early (bleeding, edema, infection, peristomal dermatitis, retraction, ischemia or externalized loop necrosis) or late complications (stenosis, obstruction, prolapse, paresthetic hernia, and fistulas) ${ }^{6}$.

A cross-sectional retrospective study of 572 records of people with ostomies treated at the Ostomized Association of Rio Grande do Norte, from 1991 to 2015, showed that dermatitis, prolapse, paraestomal hernia, and stomatal retraction were the most common complications frequently observed in this population ${ }^{7}$.

Complications can, however, be avoided with local planning of the preparation for the ostomy and using 
adequate surgical techniques ${ }^{8}$. The stomatal demarcation consists in determining limits for its preparation and can be performed by the stomatologist nurse in order to promote, during the surgical act, the creation of an opening in a suitable place that allows the adaptation of equipment for the collection of effluents with minimum discomfort for the patient ${ }^{9}$.

Following the standardization of the stomatal location significantly reduces the rate of complications, since placing the ostomy in an area that ensures the equipment adherence and is easy to visualize for the person constitutes a strategy to prevent complications such as stenosis, prolapse, retraction, and ischemia ${ }^{10}$.

The multiprofessional orientation, as well as family support, favors the adaptation to the new situation of life and improves the posture regarding self-care. The educational process in health is an instrument of socialization of knowledge, health promotion and disease prevention. Among health professionals who are always in search of educational materials in order to subsidize the care process, nurses are constantly challenged to find options that support them to work with people, groups, and communities ${ }^{11}$.

Thus, the interest about this theme arose from the experiences lived by the authors during the follow-up of people with complications in intestinal ostomies and peristomal skin. Given the importance of broadening the discussions about this problem due to the emotional, physical and socioeconomic impact caused by their increasing morbidity rates, it was, therefore, necessary to evaluate the meanings attributed by people with intestinal ostomies or their carers about the onset of these complications.

In view of the above, the study aims to present the meanings attributed by participants or their caregivers in relation to the complications of the ostomy and peristomal skin in a public reference service in the region of Cariri.

\section{METHODS}

This is a descriptive study with a qualitative approach developed from the dissertation project presented to the Postgraduate Program of the Professional Master's
Degree in Technology and Innovation in Nursing at the University of Fortaleza (UNIFOR).

For qualitative research, the interpretative approach of the world and of society must be understood according to the perspective of those who experience it, which implies that the object of research is understood as being socially constructed. In this way, qualitative research becomes important for the study of lived experience, the long and complex processes of social interaction ${ }^{12}$.

According to the referral service to the person with ostomy, for the municipality of Juazeiro do Norte, state of Ceará, there are 73 individuals with intestinal ostomies enrolled in the Health Care Program of the Ostomized Person of the State Health Department of the State of Ceará. Of these, 25 did not attend the collection period and six did not agree to participate in the study, making a total of 42 interviewees: 24 with stomies and 18 caregivers.

During the meetings, the objectives of the research and the Term of Free and Informed Consent (TFIC) were presented. Data collection was performed through interviews recorded by a mobile application and with the help of a structured script adapted from the Health Care Program of the Ostomized Person of the State of Ceará that contemplated issues related to complications in the stomies and peristomal skin. After being recorded, respondents' answers were transcribed in full to be analyzed and codified in chronological order by the letter $\mathrm{E}$ for the participants with ostomies and $\mathrm{C}$ for the participant caregivers, followed by Arabic numeration.

The most reliable way of preserving or accurately reproducing the content of the interview is by registering the notes or using a recorder, since the limits of human memory would not allow the retention of the whole information, leading to possible distortions arising from the subjective elements projected during the reproduction of the interview ${ }^{12}$.

Data analysis was performed using the Bardin content analysis technique, following the steps of preanalysis, material exploration, and treatment of results, inference, and interpretation. Content analysis is a set of methodological tools that aims to analyze different forms of communication, verbal or non-verbal, obtained through interviews or direct observation, whose material extracted after thorough and exhaustive analysis is classified/separated into themes or categories ${ }^{13}$. 
Participation in the study was voluntary, through the signature of the TFIC and based on the Resolution of the National Health Council No. 466/12, which "incorporates, from the point of view of the individual and of the collectivities, bioethical referents as autonomy, not maleficence, beneficence, justice and equity " and states in Chapter IV that respect for human dignity requires that all research be conducted after free and informed consent of the subjects, individuals or groups that express their consent to participate in the research.

In this sense, the participants were guaranteed their anonymity, their privacy, their right of autonomy regarding the freedom to participate or not of the research, as well as to give up at any stage of their realization. The project was appraised and approved by the Research Ethics Committee of UNIFOR under opinion 2.542.686 and CAAE 83103518.4.0000.5052.

The authors declare that there are no political and/ or financial conflicts of interests associated with the provision of the materials used in the study, nor any type of funding for its realization.

\section{RESULTS AND DISCUSSION}

The speech evidenced from the analysis of the participants points to the causalities attributed to the complications of the ostomies and peristomal skin.

For some interviewees, the clinical situation arises from the duration of the scholarship:

It turns reddish when it passes from 5 to 6 days and it scratches, then, when I take the bag, I do the cleaning, then it goes back to normal. Yeah, and then it gets irritated right away. It gets itchy and red. (E42)

Among the main complications in the peristomal skin, dermatitis is the most common. It is a pathological process involving all skin lesions around the stoma manifested through signs such as erythema, flushing, pain, heat or primary skin lesions ${ }^{14}$. Thus, the overall treatment strategy for most peristomal skin complications after the correct diagnosis is to adjust the collecting equipment and add topical therapy to promote healing ${ }^{15}$. Thus, the choice of adequate collection equipment by the stomatherapist coupled with the teaching of self-care is fundamental to avoid the appearance of this type of complication ${ }^{16}$.

As a general rule, the best collecting equipment is the simplest, most comfortable, practical, safe, discreet, lowest cost and that suits the stoma and protects the peristomal skin, so it is up to the professional to explain to the person with advantages and disadvantages of each bag according to individual characteristics and personal choice ${ }^{1}$.

For some participants with ostomies, the prolapse presented in the ostomy is due to the physical effort:

This happened like this, it was the weight I carried once. I made a mistake, I didn't know, you see? Then, I was carrying four stakes, working as I really like to work, then when I threw the stakes I felt a pain, felt a pain, spent like 3 days at home, then I went to the hospital, right, through the weight I've carried. (E2, E5, E23)

Prolapse is a type of late complication resulting from the exteriorization of the mobile intestinal segment that may result from abnormalities of the abdominal structure or difficulty in making the ostomy ${ }^{17}$. It is an uncommon complication in ileostomies (6\%) and colostomies (5\%), usually related to a paraestomal hernia, obesity, and insertion of stomies in areas of previous incisions or poor stomatal performance, respectively ${ }^{18}$.

In such cases, the use of flat plates and two-piece systems are most suitable. A bag of sufficient size should be used to accommodate the loop and effluent preceded by adequate measurement of the larger diameter of the loop to pass through the opening without trauma. The use of a belt can help support the bag and keep the plate supported ${ }^{1,17}$.

In the report of the caregivers, it was evidenced that the complications in peristomal skin are related to the type of bag and adhesiveness.

Sometimes the bag won't stick, it won't hold, I dunno if it is because of too much sweat. It won't stick and it loses, it's a lot of work. We go sticking with everything that people tells us, and it works, because it makes us spend bags. It isn't easy! Once he used shoemaker's glue.. (C1, C3, C4, C6, C7, C8, C9).

Improperly indicated collecting equipment, as well as the quality of the material and the non-use of 
adjuvants, compromise the integrity of the peristomal skin. The individual characteristics of each individual, the location of the stoma and the surgical technique used should be taken into account during the indication of the collection and adjuvant equipment ${ }^{19}$.

Most people with bowel ostomies tend to use drainable bags, which can be emptied periodically and replaced between 3 and 7 days. However, people with regular bowel movements, with evacuation every 2 days, for example, may opt for the use of a closed bag exchanged at each elimination ${ }^{1}$.

The purchase of the grants and other supplies is guaranteed free of charge by registering in the association of the ostomates of each municipality, according to the assessment of the stoma and skin peristaltic by the nurse of the service.

The assessment of the estomatherapy nursing at this moment is of fundamental importance, since nursing care requires the professional to be able to act and think critically about the information obtained in the anamnesis, thus providing subsidies to reflect on the care process offered and on the quality of care focused on the rehabilitation of the person with intestinal stomies ${ }^{18,20}$.

Regarding the reason that the participants relate the complications presented in ostomies and peristomal skin, the surgical procedures were cited as the main cause:

The doctor made it wrong. Instead of keeping two fingers out, he made it straight, inside more than outside, so I suffer from that. When the bag falls, the feces run down. If it was one or two fingers more to outside, wouldn't hurt the tummy. (E12, E18)

The onset of complications in the postoperative period burden health institutions, as they not only make treatment expensive, they increase hospital staying time, compromise the prognosis and increase the workload of the staff, further damaging the person's self-esteem with intestinal ostomies and their prospects for improvement.

In view of the facts, the incorporation of a stoma therapist nurse at the service, especially in those who have few resources, greatly reduces the complications in the stoma and the peristomal skin. Another strategy to reduce these complications is the preoperative demarcation of the ostomy ${ }^{21}$.

A study carried out with medical surgeons in the period from 2014 to 2015 revealed that the assistance provided by these professionals to people with ostomies was basically restricted to the manufacturing of the ostomy and initial clinical conduct, requiring the referral of these people to specialized services in order to ensure continuous follow-up after discharge from hospital ${ }^{22}$.

In this context, nursing in stomatherapy has been highlighted as a facilitator of the care process, occupying a differentiated position among the professionals who provide assistance to people with ostomies, since, besides accompanying the entire process of making the ostomy, it acts to prevent complications and prepare for the process of adaptation and self-care.

The inappropriate use of the bags was also cited by the caregiver participants as the cause for the appearance of dermatitis in the peristomal skin:

I think it was the liquid with acid that burnt the skin, I dunno if the plate or the bag was misplaced. (C2, C5)

Irritative dermatitis caused by the contact of the effluent with the peristomal skin leads to the appearance of a hyperemic, humid and painful area. This is often because, when cutting the bag, the hole is not suitable for the size of the ostomy. In such cases, the reassessment of the self-care technique being used is important to improve the ability of the person with the bowel or his caregivers to provide a cut that is more suited to his or her stomach ${ }^{14}$.

There are participants who do not attribute causality to the complications in the ostomy and peristomal skin:

I do not know not (laughs). I do not understand these things at all.(E3)

Self-care guidelines should be started as soon as the ostomy is indicated and can last until the person is fully rehabilitated with an ostomy. Such orientations are of fundamental importance since the stomies can be considered, by many people, mutilating surgery that causes disorders from a biopsychosocial point of view and radical changes in their QoL, alimentary and hygienic habits ${ }^{22}$.

In this way, the educational process cannot be fragmented, since subjects, imbued with multidimensionality, need holistic and integral care. Thus, the guidelines aim to help the person with the ostomy to overcome the difficulties 
of daily life and achieve the desired social inclusion, from the changes that occur in their lives resulting from the ostomy ${ }^{23}$.

\section{CONCLUSION}

From the analysis of the speeches from the participants of this investigation, the meanings attributed in relation to the complications of the stoma and peristaltic skin in a referral service in the Cariri region were related to the duration of the bag, physical effort, type of bag and adhesiveness, surgical procedures, inappropriate use of the bags and others that do not attribute causality to the complications.

In view of the above, it is possible to observe that the occurrence of complications in ostomies and peristomal skin is quite common among the participants interviewed, either due to problems related to the handling and characteristics of the equipment or to the presence of risk factors that may predispose to the appearance of these complications

In general, it was evidenced that such complications were not directly related to the lack of information of the participant and their caregivers regarding the care with the ostomy and peristomal skin, but to the way in which the health professionals are managing this process.

It is important to emphasize the need for nursing consultations focused not only on the guidelines regarding care with the ostomy and peristomal skin, but in the periodic evaluation that discusses, explains and demonstrates the techniques for the adequate handling of the collecting equipment according to the individual characteristics of each patient (type of stoma, diameter, shape, height, allergies, personal preference, etc.), ensuring that this information is reproduced at a later date.

The individual's understanding and perspectives on the process of adaptation and possible reversal of the case significantly influence his or her capacity for self-care. The making of an ostomy implies a process marked by the pain, physical and psychological suffering that affects the health team, the participant and their relatives. It is a slow adaptation process that often affects people of productive age and brings negative repercussions from an affective, economic, interpersonal and professional point of view.

Thus, the provision of specialized assistance is necessary so that the guidelines of the professionals are directed to the individual needs of each participant, in order to obtain adherence to self-care, social reintegration, and withdrawal of doubts, since health care is based on an interpersonal process centered on the integral care of the individual and his family.

\section{CONTRIBUTION OF AUTHORS}

Conceptualization, Feitosa YS and Sampaio LRL; Methodology, Feitosa YS; Sampaio LRL; Viana MCA; Sacramento KPN and Galdino YLS; Research, Feitosa YS; Carvalho TB; Silva FM; Moreira DAA and Mendonça FAC; Writing - First version, Feitosa YS; Sampaio LRL; Carvalho TB and Moreira DAA; Writing - Review \& Edition, Sampaio LRL; Acquisition of Financing, Feitosa YS; Resources, Feitosa YS; Supervision, Sampaio LRL.

\section{REFERENCES}

1. Oliveira RG. Blackbook enfermagem. 1a ed. Belo Horizonte: Blackbook; 2016.

2. Maurício VC, Souza NVDO, Costa CCP, Dias MO. The view of nurses about educational practices targeted at people with a stoma. Esc Anna Nery. 2017;21(4):21-4. https://doi. org/10.1590/2177-9465-EAN-2017-0003

3. Jayarajah U, Samarasekara AM, Samarasekera DN. A study of long-term complications associated with enteral ostomy and their contributory factors. BMC Res Notes. 2016;9(1):1-6. https://doi.org/10.1186/s13104-016-2304-z

4. Almeida EJ, Silva AL. Caracterização do perfil epidemiológico dos estomizados em hospitais da Secretaria de Estado de Saúde do Distrito Federal. ESTIMA, Braz J Enterostomal
Ther. 2015;13(1):11-6. $\quad$ https://doi.org/10.5327/Z18063144201500010004.

5. Instituto Nacional de Câncer. Incidência de câncer no Brasil [Internet]. Rio de Janeiro; 2018. [citado 20 Set 2018]. Disponível em: http://www.inca.gov.br/estimativa/2018/ sintese-de-resultados-comentarios.asp

6. Rocha JJR. Estomas intestinais (ileostomias e colostomias) e anastomoses intestinais. Medicina, Ribeirão Preto. 2011;44(1):51-6.

7. Dantas FG. Prevalência de complicações em pessoas com estomias urinárias e intestinais. Revista Enfermagem Atual. 2017;82(1):56-61. 
8. Miguel VM, Jiménez EF, Parajó CA. Current status of the prevention and treatment of stoma complications. A narrative review. Cir Esp. 2014;92(3):149-56. https://doi. org/10.1016/j.ciresp.2013.09.011

9. Pengelly S, Reader J, Jones A, Roper K, Douie WJ, Lambert AW. Methods for siting emergency stomas in the absence of a stoma therapist. Ann R Coll Surg Engl. 2014;96(3):216-8. https://doi.org/10.1308/003588414X13814021679717

10. Forsmo HM, Pfeffer $F$, Rasdal A, Sintonen $H$, Körner $H$, Erichsen C. Pre and postoperative stoma education and guidance within an enhanced recovery after surgery (ERAS) programme reduces length of hospital stay in colorectal surgery. Int J Surg. 2016;36(1):121-6. https://doi. org/10.1016/j.jijsu.2016.10.031

11. Yamada BA, Ferrola EC, Azevedo GR, Blanes L, Rogenski NM, Santos VLCG. Estomaterapia - Competências do enfermeiro estomaterapeuta Ti Sobest ou do enfermeiro estomaterapeuta. Estima. 2008;6(1) [cited 12 Sept 2018]. Available at: http://www. sobest.org.br/texto/11

12. Gil AC. Como elaborar projetos de pesquisa. 6a ed. São Paulo: Atlas; 2017.

13. Bardin L. Análise de conteúdo. 1a. ed. São Paulo: Edições 70; 2016.

14. Santos VLCG, Cesaretti IUR. Assistência em estomaterapia cuidando de pessoas com estomia. São Paulo: Atheneu; 2015.

15. Steinhagen E, Colwell J, Cannon L. Intestinal stomas Postoperative stoma care and peristomal skin complications. Clinics Colon Rectal Surgery. 2017;30(3):184-92. https://doi. org/10.1055/s-0037-1598159.

16. Secretaria de Atenção à Saúde. Portaria n. 400 de 16 de novembro de 2009 [Internet]. Brasília, DF; 2009. Available at: $\quad$ http://www.ans.gov.br/images/stories/noticias/pdf/p sas 4002009 ostomizados.pdf

17. Miranda SM, Luz MHBA, Sonobe HM, Andrade EMLR, Moura ECC. Caracterização sociodemográfica e clínica de pessoas com estomia em Teresina. ESTIMA, Braz. J. Enterostomal Ther. 2016;14(1):29-35. https://doi.org/10.5327/Z1806$\underline{3144201600010005}$

18. Reis FF. Transição para a vivência com uma ostomia: intervenções de enfermagem [tese]. Porto: Universidade do Porto; 2015.

19. Collet JÁ, Silva FP, Aymone JLF. Bolsas coletoras utilizadas por estomizados: uma análise tridimensional. Design \& Tecnologia. 2016;11(1):1-10.

20. Moraes JT, Amaral CFS, Borges EL, Ribeiro MS, Guimarães EAA. Serviços de atenção ao estomizado: análise diagnóstica no estado de Minas Gerais, Brasil. Cad Saúde Colet. 2014;22(1):101-8. https://doi.org/10.1590/1414$\underline{462 \times 201400010015}$

21. Clarke L, Abbott $H$, Sharma P, Eglinton TW, Frizelle FA. Impact of restenting for recurrent colonic obstruction due to tumour ingrowth. BJS Open. 2017;1(6):202-6. https://doi. org/10.1002\%2Fbjs5.34

22. Moraes JT, Silva AE, Silva MDM, Guimarães RO, Ferraz GB. A percepção de cirurgiões sobre o cuidado em estomias. J Health Sci. 2017;19(1):14-8. https://doi.org/10.17921/24478938.2017v19n1p14-18

23. Lenza NFB, Sonobe HM, Buetto LS, Santos MG, Lima MS. O ensino do autocuidado aos pacientes estomizados e seus familiares: uma revisão integrativa. Rev Bras Prom Saúde. 2013;26(1):138-44. 